\title{
THE STATE IN THE SECTOR OF MILK PRODUCTION IN EUROPEAN UNION AND IN OUR COUNTRY
}

\author{
P. Perišić, Z. Skalicki, V. Bogdanović \\ Agricultural Faculty, Nemanjina 6, 11080 Belgrade-Zemun, Republic of Serbia \\ Corresponding author: perisicp@agrif.bg.ac.rs \\ Invited paper
}

Abstract: The paper gives an analysis of the state in milk production from the aspect of total produced quantities of milk and total purchased quantites of milk by the diaries in EU. The number of farms engaged in cattle production has been analysed, along with the farms engaged in milk production. Trend in development of cattle breeding in EU is going in the direction of decreasing the number of farms raising the breeding stocks of dairy cows and to the simultaneous increase in the number of cows per farm for milk production with constant increase of the quantity of milk produced per cow. In 2008 the number of cows per farm in EU27 was on average 9.8 cows, in EU25 on average 16.6 cows, with great variation among member countries observed. Average milk yield in total cow population in 2008 in EU15 was $6646 \mathrm{~kg}$, in EU25: $6357 \mathrm{~kg}$ and in EU27: 6133kg. In Serbia the average milk yield in registered cows of Simmental breed is about $4500 \mathrm{~kg}$, and in Holstein Friesian breed around $8700 \mathrm{~kg}$. It is important to emphasize that in Serbia there is a far less number of cows under controlled milk yield (around 5.5\% Simmental cows in total number), and that there is a decline observed in the number of cattle in Serbia in the last decade per average rate of 2-3 $\%$ annualy.

Key words: farms, cattle, milk yield, milk production.

\section{Introduction}

Cattle breeding, as a leading branch in livestock production, participate with between 60 and $70 \%$ in total livestock production in more developed European countries, while in Serbia this participation is below 50\% (some estimations state $40-45 \%$ ). A trend in the development of cattle breeding in EU goes in the direction of decreasing the number of farms raising the breeding stocks of dairy cows and simultaneous increase in the number of cows per farms engaged in milk production with constant increase in the quantity of milk produced per cow. In Serbia, according to the Inventory from 2002, 97.61\% farms had 1 to 5 cows and they owned $87 \%$ heads in a total number of cows in Serbia. In the last 10 
years number of farms engaged in raising cattle has declined, likewise the number of cattle heads (per annual rate of 2 to $3 \%$ ). In 2008 number of cows per farm in EU27 was on average 9.8 cows, in EU25 on average 16.6 cows, with great variations between member countries. Average milk yield in total cow population in 2008 (Eurostat and Agriculture and Rural Development DG-C.4, 2009) in EU15 was $6646 \mathrm{~kg}$, in EU25: 6357kg and EU27: 6133kg. Average milk yield in registered Simmental cows in Serbia was $4500 \mathrm{~kg}$, and in Holstein Friesian breed around $8700 \mathrm{~kg}$. It is important to state that in Serbia there is a far less cows under a controlled milk yield (around 5.5\% Simmental breed), while for example, in Germany about 19\% animals of Simmental breed are under milk yield control, in Slovenia about $15 \%$, Austria about $15 \%$ and Hungary about $11 \%$.

\section{Milk production - milk production balance}

An overall world milk production includes five milk types such as follows: cow, buffalo, goat, sheep and camel milk. The average yield in total world production, as per FAO data in the last five years is as follows: $83.89 \%$ cow, $12.22 \%$ buffalo, $2.23 \%$ goat, $1.43 \%$ sheep and $0.23 \%$ camel milk.

Throughout the world, according to $\mathrm{FAO}$, an overall milk production in recent years ranges from 650 and 700 million tonnes with average annual growth rate of $1.85 \%$. The records for the countries the greatest milk producers in the period from 2005-2008 are shown in Table 1. The production of milk in Serbia has been compared with overall world milk production and described as more than modest one since in 2008 it participated with $0.25 \%$ in total world milk production. The countries of Oceania produce $35 \%$ of dairy processed products for trade on international market (Table 2).

Table 1. Milk production in countries with highest world milk production in the period 20052008 (in million tonnes)

\begin{tabular}{|l|c|c|c|c|c|}
\hline Country & 2005 & 2006 & 2007 & 2008 & Udeo u 2008. \\
\hline India & 95,6 & 100,0 & 102,9 & 106,0 & $15,29 \%$ \\
\hline SAD & 80,3 & 82,5 & 84,2 & 86,5 & $12,48 \%$ \\
\hline China & 32,0 & 37,5 & 41,1 & 44,5 & $6,42 \%$ \\
\hline Russia & 31,1 & 31,4 & 32,2 & 32,8 & $4,73 \%$ \\
\hline Pakistan & 29,4 & 31,2 & 32,5 & 33,8 & $4,88 \%$ \\
\hline Germany & 28,5 & 28,0 & 27,9 & 28,1 & $4,05 \%$ \\
\hline France & 25,7 & 25,0 & 24,5 & 24,7 & $3,56 \%$ \\
\hline Serbia & 1,8 & 1,7 & 1,7 & 1,7 & $0,25 \%$ \\
\hline World total & 645,0 & 664,1 & 676,3 & 693,2 & $100,00 \%$ \\
\hline
\end{tabular}

Source: http:// faostat.fao.org 
Graph 1. Rise in milk production from 2006/08 to 2018

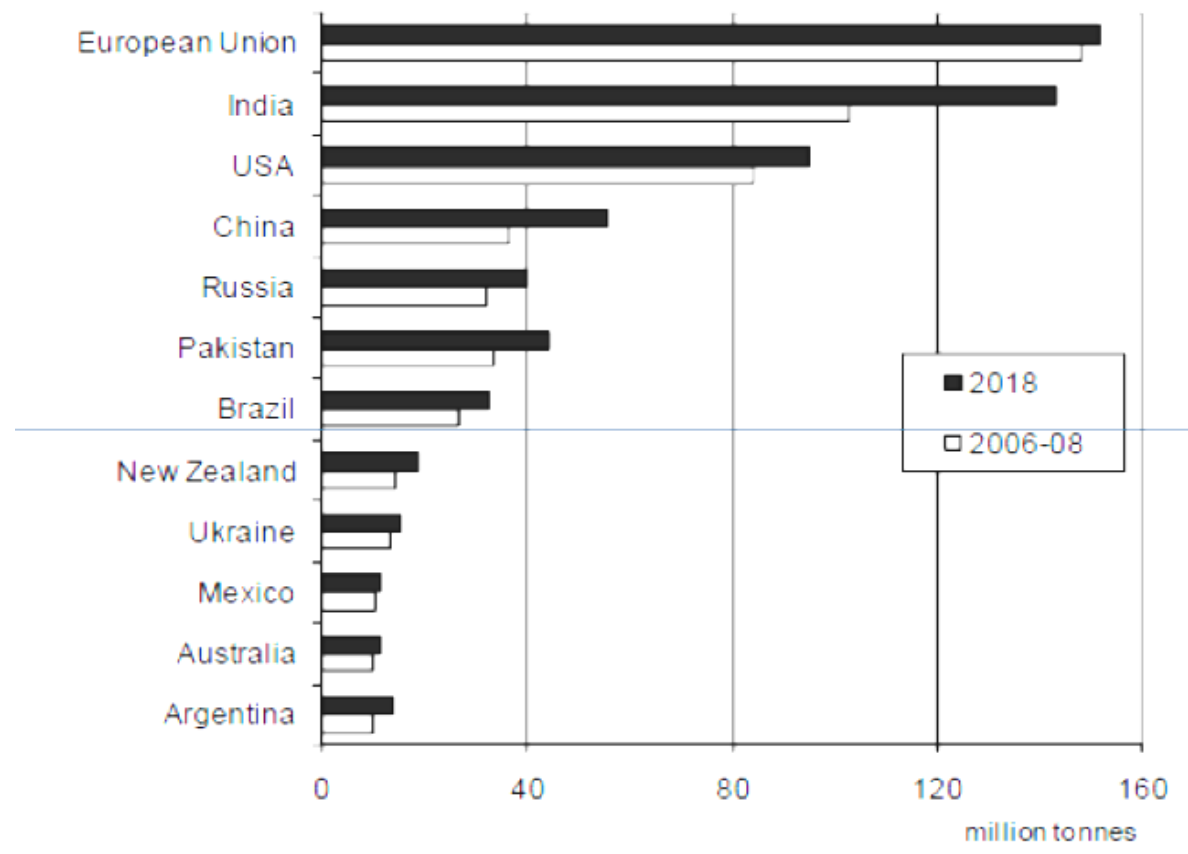

Source: OECD/FAO, 2009

Table 2. The most important importers and exporters of milk in period 2005-2008 (in million tonnes)

\begin{tabular}{|l|c|c|c|c|c|c|c|c|c|}
\hline \multicolumn{5}{|c|}{ Net import } & \multicolumn{5}{c|}{ Net export } \\
\hline Country & 2005 & 2006 & 2007 & 2008 & & 2005 & 2006 & 2007 & 2008 \\
\hline Russia & 1,9 & 2,6 & 2,9 & 3,1 & $\begin{array}{c}\text { New } \\
\text { Zealand }\end{array}$ & 10,6 & 11,6 & 11,2 & 9,8 \\
\hline Mexico & 2,8 & 1,8 & 1,9 & 2,1 & EU & 11,6 & 7,7 & 7,0 & 6,9 \\
\hline China & 2,9 & 1,8 & 1,5 & 1,4 & Australia & 4,3 & 3,8 & 3,0 & 2,8 \\
\hline Algeria & 1,9 & 1,5 & 1,5 & 1,4 & Belorus & 1,6 & 1,6 & 1,6 & 1,8 \\
\hline $\begin{array}{l}\text { Saudi } \\
\text { Arabia }\end{array}$ & 1,4 & 1,3 & 1,0 & 0,7 & Argentina & 1,7 & 2,1 & 1,1 & 1,2 \\
\hline Egypt & 0,7 & 1,5 & 1,5 & 1,4 & SAD & 2,3 & 1,0 & 1,2 & 1,4 \\
\hline $\begin{array}{l}\text { World } \\
\text { total }\end{array}$ & 42,7 & 39,3 & 37,8 & 36,5 & $\begin{array}{c}\text { World } \\
\text { total }\end{array}$ & 42,8 & 39,4 & 38,0 & 36,4 \\
\hline
\end{tabular}

Source: http:// faostat.fao.org

An overall milk production in the member countries of the European Union is shown in Table 3. It can be observed that in the studied period the production was on an approximately equalised level, certainly due to the planning of production and respecting the permitted production quotas. Out of annual milk 
production the dairies in EU purchase over $90 \%$ milk (Table 3), while in Serbia the dairies purchase $50 \%$ of produced milk quantities.

Table 3. Milk quantities purchased by diaries, as \% in total quantity of milk produced

\begin{tabular}{|c|c|c|c|c|c|c|c|c|}
\hline \multirow[b]{2}{*}{ Country } & \multicolumn{2}{|c|}{2005} & \multicolumn{2}{|c|}{2006} & \multicolumn{2}{|c|}{2007} & \multicolumn{2}{|c|}{2008} \\
\hline & $\begin{array}{l}000 \mathrm{t} \\
\text { milk }\end{array}$ & $\begin{array}{c}\% \text { in } \\
\text { total } \\
\text { quantity }\end{array}$ & $\begin{array}{l}000 \mathrm{t} \\
\text { milk }\end{array}$ & $\begin{array}{c}\% \text { in } \\
\text { total } \\
\text { quantity }\end{array}$ & $\begin{array}{l}000 \mathrm{t} \\
\text { milk }\end{array}$ & $\begin{array}{c}\% \text { in } \\
\text { total } \\
\text { quantity }\end{array}$ & $\begin{array}{l}000 \mathrm{t} \\
\text { milk }\end{array}$ & $\begin{array}{c}\% \text { in } \\
\text { total } \\
\text { quantity }\end{array}$ \\
\hline EU 27 & 148905 & 89,7 & 148082 & 89,6 & 147079 & 89,8 & 148718 & 90,3 \\
\hline Belgium & 3082 & 93,1 & 2917 & 97,3 & 2943 & 97,8 & 3098 & 92,0 \\
\hline Bulgaria & 1287 & 62,4 & 1299 & 64,6 & 1148 & 64,9 & 1143 & 62,9 \\
\hline Czech Rep. & 2813 & 90,4 & 2767 & 86,5 & 2839 & 86,1 & 2801 & 86,8 \\
\hline Denmark & 4587 & 97,1 & 4627 & 97,1 & 4619 & 97,1 & 4656 & 98,4 \\
\hline Germany & 28453 & 96,2 & 27995 & 96,0 & 28403 & 96,2 & 28656 & 95,8 \\
\hline Estonia & 670 & 85,3 & 692 & 87,6 & 692 & 85,8 & 702 & 86,3 \\
\hline Ireland & 5100 & 99,2 & 5272 & 99,3 & 5268 & 99,5 & 5199 & 98,2 \\
\hline Greece & 761 & 86,7 & 764 & 87,7 & 774 & 92,5 & 760 & 90,8 \\
\hline Spain & 6561 & 89,9 & 6378 & 91,3 & 6335 & 90,4 & 6500 & 89,8 \\
\hline France & 24675 & 94,8 & 24367 & 94,0 & 23426 & 98,1 & 24516 & 97,2 \\
\hline Italy & 10975 & 93,1 & 10989 & 92,8 & 11062 & 92,8 & 10962 & 95,8 \\
\hline Cyprus & 147 & 98,6 & 149 & 93,5 & 144 & 100,0 & 152 & 100,0 \\
\hline Latvia & 807 & 62,2 & 812 & 72,9 & 838 & 75,2 & 844 & 75,1 \\
\hline Lithuania & 1854 & 64,8 & 1885 & 68,8 & 1931 & 69,8 & 1879 & 70,4 \\
\hline \begin{tabular}{|l|} 
Luxembourg \\
\end{tabular} & 270 & 96,3 & 268 & 95,1 & 274 & 94,6 & 278 & 95,3 \\
\hline Hungary & 1929 & 78,7 & 1844 & 78,5 & 1842 & 78,6 & 1813 & 78,6 \\
\hline Malta & 41 & 100,0 & 41 & 100,0 & 41 & 100,0 & 40 & 100,0 \\
\hline Netherlands & 10845 & 96,6 & 10995 & 96,9 & 11128 & 97,0 & 11620 & 97,2 \\
\hline Austria & 3114 & 84,2 & 3147 & 85,0 & 3155 & 84,4 & 3196 & 85,0 \\
\hline Poland & 11923 & 74,0 & 11982 & 73,7 & 12096 & 72,3 & 12425 & 71,6 \\
\hline Portugal & 2061 & 93,2 & 1984 & 93,3 & 1969 & 93,3 & 1890 & 99,8 \\
\hline Romania & 4977 & 22,3 & 5285 & 21,4 & 4997 & 22,7 & 4854 & 21,6 \\
\hline \begin{tabular}{|l|} 
Slovenia \\
\end{tabular} & 659 & 77,1 & 642 & 79,6 & 666 & 79,6 & 659 & 79,5 \\
\hline Slovakia & 1100 & 88,0 & 1092 & 88,1 & 1075 & 89,7 & 1057 & 89,5 \\
\hline Finland & 2433 & 97,1 & 2413 & 97,3 & 2356 & 97,3 & 2311 & 97,8 \\
\hline Sweden & 3206 & 98,7 & 3130 & 100,0 & 2986 & 100,0 & 2987 & 100,0 \\
\hline U K & 14574 & 96,3 & 14348 & 97,0 & 14073 & 97,0 & 13719 & 97,3 \\
\hline EU 25 & 142641 & 92,3 & 141498 & 92,3 & 140934 & 92,9 & 142721 & 92,9 \\
\hline EU 15 & 120698 & 95,1 & 119594 & 95,2 & 118770 & 96,1 & 120439 & 96,1 \\
\hline
\end{tabular}

Source: Eurostat and Agriculture and Rural Development DG-C.4, 2009 


\section{The size of farms for milk production in EU countries}

An average number of cattle on farms in EU 27 in 2007 was 26.9 heads of all categories of cattle wherein 9.8 were cows. There are great variations among the countries shown in Table 4.

Table 4. Number of cattle and dairy cows on farm and changes in number of farms and number of dairy cows

\begin{tabular}{|c|c|c|c|c|}
\hline Country & $\begin{array}{c}\text { Number of cattle per } \\
\text { farm (2007) }\end{array}$ & $\begin{array}{c}\text { Number of dairy cows } \\
\text { per farm (2007) }\end{array}$ & $\begin{array}{c}\text { Number of farms } \\
(\% \text { 2007/2005) }\end{array}$ & $\begin{array}{c}\text { Number of dairy cows } \\
(\% 2007 / 2005)\end{array}$ \\
\hline Belgium & 93,1 & 39,3 & $-6,5$ & $-2,4$ \\
\hline Bulgaria & 4,5 & 2,9 & $-11,7$ & $-1,0$ \\
\hline Czech Rep. & 101,6 & 74,1 & $-9,4$ & $-2,8$ \\
\hline Denmark & 100,3 & 101,4 & $-10,4$ & $-1,7$ \\
\hline Germany & 74,7 & 40,3 & $-4,4$ & $-1,9$ \\
\hline Estonia & 34,1 & 17,7 & $-20,8$ & $-3,3$ \\
\hline Ireland & 88,0 & 49,6 & $-5,5$ & $-1,1$ \\
\hline Greece & 62,6 & 19,6 & $-9,9$ & $-3,2$ \\
\hline Spain & 34,0 & 26,1 & $-6,4$ & $-1,4$ \\
\hline France & 46,3 & 41,0 & $-5,5$ & $-0,9$ \\
\hline Italy & 43,3 & 30,1 & 1,0 & 0,8 \\
\hline Cyprus & 201,5 & 94,4 & 0,0 & $-3,4$ \\
\hline Latvia & 8,4 & 4,2 & $-7,6$ & 2,8 \\
\hline Lithuania & 5,9 & 3,2 & $-16,3$ & $-10,7$ \\
\hline Luxembourg & 129,7 & 36,7 & 6 & 1 \\
\hline Hungary & 35,5 & 21,8 & $-14,5$ & $-3,9$ \\
\hline Malta & 82,2 & 42,5 & 2,7 & 5,3 \\
\hline Netherlands & 106,7 & 59,9 & 2,0 & 1,2 \\
\hline Austria & 25,7 & 10,5 & $-4,9$ & $-1,3$ \\
\hline Poland & 8,2 & 4,3 & $-5,5$ & $-1,5$ \\
\hline Portugal & 25,4 & 20,2 & $-8,1$ & $-2,6$ \\
\hline Romania & 2,6 & 1,6 & $-5,7$ & $-2,2$ \\
\hline Slovenia & 11,6 & 6,5 & $-7,7$ & $-4,3$ \\
\hline Slovakia & 32,5 & 15,4 & $-7,7$ & $-4,3$ \\
\hline Finland & 49,8 & 20,6 & $-8,2$ & $-3,7$ \\
\hline Sweden & 65,3 & 52,1 & $-9,3$ & $-3,1$ \\
\hline UK & 105,2 & 69,4 & 3,0 & $-2,8$ \\
\hline EU 25 & 40,4 & 16,6 & $-6,3$ & $-1,5$ \\
\hline EU 27 & 26,9 & 9,8 & $-6,3$ & $-1,6$ \\
\hline
\end{tabular}

Source: Eurostat and Agriculture and Rural Development DG-C.4, 2009

Thus in Germany, for example, there were 40.3 cows per farm, in Slovenia 6.5 cows per farm for milk production and 11.6 cattle per farm for cattle breeding. A trend in development of cattle breeding in $\mathrm{EU}$ is directed towards declining in the number of farms that raise breeding stocks of dairy cows and simultaneous 
increase in the number of cows per farm with constant rise of the quantity of milk produced per cow. As a consequence of such events it can happen that the $\%$ of decline of number of farms be greater than the $\%$ of decline of number of milking cows (because of the increased number of cows per farm), and that an overall milk production is maintained on approximately the same level and with decreased number of cows since the production of milk per cow is being increased further on.

When we analyse the participation of farms according to their size (number of cattle heads per farm) it can be observed that the greatest participation is of the medium farms with 30 to $49(11.9 \%)$ cattle heads and of those with 50 to 99 heads (18.6\%), as well as of large farms with more than 100 heads of cattle participating with $34.3 \%$ in total number of cattle farms which raise $58 \%$ of total number of cattle (Table 5). The participation of farms for milk production in total number of farms for milk production is greatest for small farms owning 1 to 2 cows $(67.5 \%)$ and farms with 3 to 9 cows $(13.7 \%)$. The situation in cattle breeding in the countries which have lately become the members of EU (in Bulgaria the average number of cows per farm is 2.9 , and in Romania 1.6) certainly contributed to such a great participation of petty farms in total number of farms for milk production. As a consequence thereof an average size of farms observed per number of cows on the farm which produce milk differs significantly between EU 25 (16.6 cows per farm) and EU 27 (9.8 cows per farm). However, if we observe the participation of the number of cows on large, medium and small farms in total number of cows for milk production, it can be seen that in the groups of farms with 30 and more cows, which make total of $9.4 \%$ in total number of farms, they raise $68 \%$ of total number of cows in EU 27 (Table 5).

Table 5. Number of dairy cows per groups of farms and participation of group of farms in total number (\%) in EU 27

\begin{tabular}{|c|c|c|c|c|}
\hline Size of farm & Cattle heads & Cattle farms & Cows & $\begin{array}{c}\text { Farms for milk } \\
\text { production }\end{array}$ \\
\hline $1-2$ heads & $2,2 \%$ & $5,1 \%$ & $8,7 \%$ & $67,5 \%$ \\
\hline $3-9$ heads & $4,5 \%$ & $11,1 \%$ & $6,7 \%$ & $13,7 \%$ \\
\hline $10-19$ heads & $4,3 \%$ & $10,7 \%$ & $8,3 \%$ & $5,9 \%$ \\
\hline $20-29$ heads & $4,3 \%$ & $8,3 \%$ & $8,3 \%$ & $3,4 \%$ \\
\hline $30-49$ heads & $8,0 \%$ & $11,9 \%$ & $17,0 \%$ & $4,4 \%$ \\
\hline $50-99$ heads & $18,7 \%$ & $18,6 \%$ & $25,6 \%$ & $3,7 \%$ \\
\hline$\geq 100$ heads & $58,0 \%$ & $34,3 \%$ & $25,4 \%$ & $1,3 \%$ \\
\hline Total & $100 \%$ & $100 \%$ & $100 \%$ & $100 \%$ \\
\hline
\end{tabular}

Source: Eurostat and Agriculture and Rural Development DG-C.4, 2009

In Serbia, according to the Inventory from 2002, the $97.61 \%$ farms had 1 to 5 cows and they owned $87 \%$ cows in total number of cows in Serbia. According to 
Popović (2008) a prevalent portion of farms has no prerequisites to produce quality milk. For that reason, and for the reason of splitting and disorganisation of farms an average price of milk in Serbia is at considerably lower level in relation to milk prices in more developed countries.

Table 6. Changes in number of farms for milk production and number of dairy cows in EU 27

\begin{tabular}{|c|c|c|c|c|}
\hline Size of farm & $\begin{array}{c}\text { Change in } \\
\text { number of cattle } \\
\text { farms } \\
(\% 2007 / 2005)\end{array}$ & $\begin{array}{c}\text { Change in number } \\
\text { of cattle } \\
(\% \text { 2007/2005) }\end{array}$ & $\begin{array}{c}\text { Change in } \\
\text { number of } \\
\text { farms for milk } \\
\text { production } \\
(\% 2007 / 2005)\end{array}$ & $\begin{array}{c}\text { Changes in number } \\
\text { of dairy cows } \\
(\% 2007 / 2005)\end{array}$ \\
\hline $1-9$ heads & $-7,8$ & $-6,6$ & $-7,1$ & $-2,7$ \\
\hline $10-19$ heads & $-3,4$ & $-3,2$ & $-2,7$ & $-2,7$ \\
\hline $20-29$ heads & $-1,7$ & $-1,9$ & $-5,6$ & $-5,8$ \\
\hline $30-49$ heads & $-3,4$ & $-3,5$ & $-4,9$ & $-4,8$ \\
\hline $50-99$ heads & $-2,8$ & $-2,9$ & $-0,4$ & 0,2 \\
\hline$\geq 100$ heads & 0,7 & 2,2 & 4,2 & 4,6 \\
\hline EU 27 & $-6,0$ & $-0,3$ & $-6,3$ & $-1,6$ \\
\hline
\end{tabular}

Source: Eurostat and Agriculture and Rural Development DG-C.4, 2009

\section{Cow milk yield in EU countries and in Serbia}

In EU the state in breed composition in cattle is always changing, the main breeds in milk production being Holstein Friesian and Simmental breed. The average milk yield in total cow population in 2008 (Eurostat and Agriculture and Rural Development DG-C.4, 2009) in EU15 was $6646 \mathrm{~kg}$, EU25: $6357 \mathrm{~kg}$ and EU27: $6133 \mathrm{~kg}$, what is displayed in Table 7. It is interesting to stress that an average milk yield per cow is greater in the countries that base their production of milk mostly on Holstein Friesian breed and other specialised dairy breeds, therefore the highest world mean values per cow are made in Great Britain, the Netherlands, Denmark, Finland and Sweden. In the countries that also have an intensive cattle production, but with a significant participation of other breeds in milk production as well, such as for example Simmental, Brown Swiss, Montbeliarde and Norman breed, they have a somewhat lower average milk production. Typical examples are Germany with average of $6776 \mathrm{~kg}$ per cow (because of the participation of Simmental breed in overall cattle population with around 30\% and significant participation of Brown Swiss breed), as well as Austria with average of $6028 \mathrm{~kg}$ and participation of Simmental breed in overall cattle population of over $80 \%$. 
Table 7. Milk yield in cows in EU countries

\begin{tabular}{|c|c|c|c|c|}
\hline Country & $\begin{array}{l}\text { Average per cow } \\
(\mathrm{kg}) \text { in } 2005\end{array}$ & $\begin{array}{c}\text { Average per cow } \\
(\mathrm{kg}) \text { in } 2006\end{array}$ & $\begin{array}{l}\text { Average per cow } \\
(\mathrm{kg}) \text { in } 2007\end{array}$ & $\begin{array}{c}\text { Average per cow } \\
(\mathrm{kg}) \text { in } 2008\end{array}$ \\
\hline Belgium & 5622 & 5484 & 5613 & 5963 \\
\hline Bulgaria & 3700 & 3710 & 3419 & 3632 \\
\hline Czech Rep. & 6436 & 6631 & 6969 & 7008 \\
\hline Denmark & 8220 & 8337 & 8332 & 8197 \\
\hline Germany & 6834 & 6905 & 6949 & 6776 \\
\hline Estonia & 5924 & 6350 & 6717 & 6999 \\
\hline Ireland & 4632 & 4849 & 4844 & 4706 \\
\hline Greece & 4999 & 4552 & 5160 & 4936 \\
\hline Spain & 6446 & 6771 & 7013 & 7317 \\
\hline France & 6334 & 6414 & 6233 & 6463 \\
\hline Italy & 5958 & 6059 & 6015 & 5988 \\
\hline Cyprus & 5976 & 6219 & 6076 & 6441 \\
\hline Latvia & 4356 & 4452 & 4647 & 4955 \\
\hline Lithuania & 4451 & 4723 & 4774 & 4761 \\
\hline Luxembourg & 6562 & 5802 & 6822 & 6049 \\
\hline Hungary & 6768 & 6881 & 6925 & 6893 \\
\hline Malta & 5317 & 5469 & 5413 & 5543 \\
\hline Netherlands & 7298 & 7620 & 7459 & 7322 \\
\hline Austria & 5827 & 5965 & 6015 & 6028 \\
\hline Poland & 4328 & 4544 & 4518 & 4607 \\
\hline Portugal & 6361 & 6458 & 6440 & 6285 \\
\hline Romania & 3052 & 3224 & 3177 & 3272 \\
\hline Slovenia & 5478 & 5709 & 5687 & 5813 \\
\hline Slovakia & 5539 & 5901 & 5966 & 6076 \\
\hline Finland & 7776 & 7799 & 7955 & 8013 \\
\hline Sweden & 8206 & 8137 & 8155 & 8169 \\
\hline U K & 7262 & 7156 & 7118 & 7209 \\
\hline EU 15 & 6569 & 6654 & 6635 & 6646 \\
\hline EU 25 & 6224 & 6341 & 6329 & 6357 \\
\hline EU 27 & 5982 & 6093 & 6084 & 6133 \\
\hline
\end{tabular}

Source: Eurostat and Agriculture and Rural Development DG-C.4, 2009 
A similar situation can also be found in France, where besides Holstein Friesian breed in milk production a significant participation make Montbeliarde breed, Simmental breed and Normandy breed. These three mentioned countries are also significant for cattle breeding in Serbia (Perišić 1998; Perišić et al., 2009), taking into account that both breeding animals and the semen of bulls are mostly imported from Germany, Austria and France. A compromise in raising a specialised dairy and combined breeds can be seen on the example of Switzerland (although not a member country of EU), which has a great portion of population of Simmental breed crossed with Red Holstein breed wherein the effects of mass crossing can be observed in higher average production of milk per cow (Table 8), the similar data being stated by Bigler (2001) for Swiss Simmental breed, Montbeliarde, Red-White Holstein and Black-White Holstein, as well as by Strapak and Strapakov (1997) for Simmental breed and the effects of crossing in Slovakia.

In Serbia there are around 500000 cows, and the cow milk yield in overall population is unequalised and according to some estimations it ranges from 2500 $\mathrm{kg}$ in cross-breeds and in Simmental cows raised in poorer raising conditions, to the level of between 5000 and $6000 \mathrm{~kg}$ reached on the farms of the commodity producers of milk with more intensive production and more productive heads of Simmental breed or cross-breds of Simmental and Red-White Holstein Friesian breed (Perišić et al., 2002, 2008; Perišić 2007).

Observed per major breeds in milk production in Serbia (according to the Report and results of accomplished work on selection coordination measures from 2010), an average production of registered cows of Simmental breed was around $4500 \mathrm{~kg}$, and Holstein Friesian breed about $8700 \mathrm{~kg}$ in lactation. Overall average milk yield per cow in Serbia (milk yield of controlled cows and estimated milk yield of population out of milk yield control) ranged from between 3000 and 3500 $\mathrm{kg}$. In Slovenia, according to official records (http://www.kis.si), the milk yield of Holstein Friesian population under control was 7247 kg, Simmental breed $5023 \mathrm{~kg}$, and overall population $5813 \mathrm{~kg}$. In Germany the milk yield in controlled population is $8783 \mathrm{~kg}$ for Holstein Friesian breed and $6854 \mathrm{~kg}$ for Simmental breed. Milk yield in registered cows of Simmental breed in Serbia, which ranges from $4000 \mathrm{~kg}$ to $5000 \mathrm{~kg}$ milk in standard lactation depends on a great number of non-genetic factors, and also on a genetic potential for milk production which is rather unequalised (Perišić et al., 2006). A significant fact is that in Serbia there is a considerably smaller part of cows under milk yield control (in 2009, 26222 cows of Simmental and 7400 cows of Holstein Friesian breed)) in relation to overall number of cows, what for example, in Simmental breed makes about 5.5\% in total number, while for example, in Simmental breed in Germany about $19 \%$ animals are under milk control, in Slovenia about $15 \%$, Austria around 15\% and Hungary about $11 \%$. 
Milk yield in the population of Simmental cows in some European countries is shown in Table 8.

Table 8. Milk yield of Simmental cows in some European countries

\begin{tabular}{|l|c|c|c|c|c|c|c|}
\hline Country & Year & $\begin{array}{c}\text { Lactation, } \\
\text { day }\end{array}$ & $\begin{array}{c}\text { Milk, } \\
\mathrm{kg}\end{array}$ & Fat,\% & $\begin{array}{c}\text { Fat, } \\
\mathrm{kg}\end{array}$ & Proteins, \% & Proteins,kg \\
\hline Hungary & 2004 & 293 & 5023 & 3,99 & 201 & 3,43 & 175 \\
\hline Czech Republic & 2006 & 294 & 6162 & 4,08 & 252 & 3,46 & 213 \\
\hline Slovenia & 2006 & 305 & 5023 & 4,17 & 209 & 3,29 & 165 \\
\hline Slovakia & 2004 & 297 & 4919 & 4,09 & 201 & 3,30 & 162 \\
\hline Fleckvieh Switzerland & 2006 & 299 & 6847 & 3,99 & 273 & 3,24 & 222 \\
\hline Simental Switzerland & 2006 & 297 & 5681 & 3,88 & 220 & 3,30 & 187 \\
\hline Austria & 2006 & 305 & 6483 & 4,18 & 271 & 3,43 & 222 \\
\hline Norway & 2004 & 266 & 5229 & 4,15 & 217 & 3,35 & 175 \\
\hline Croatia & 2006 & 305 & 4459 & 4,07 & 181 & 3,35 & 149 \\
\hline Italy & 2006 & 293 & 6528 & 3,92 & 256 & 3,41 & 223 \\
\hline Montbeliarde - France & 2006 & 296 & 6907 & 3,91 & 270 & 3,46 & 239 \\
\hline Germany & 2006 & 316 & 6854 & 4,14 & 284 & 3,48 & 239 \\
\hline Poland & 2006 & - & 4785 & 4,01 & 192 & 3,36 & 161 \\
\hline
\end{tabular}

(www.Cattlenetwork.net)

Table 9. Number of cattle, cows and milk production per cow in Serbia

\begin{tabular}{|c|c|c|c|}
\hline \multirow{2}{*}{ Year } & \multicolumn{2}{|c|}{ Number of cattle in Serbia (000) } & \multirow{2}{*}{$\begin{array}{c}\text { Milk production } \\
\text { (000 000 lit.) }\end{array}$} \\
\cline { 2 - 3 } & Total number & $\begin{array}{c}\text { Cows and pregnant } \\
\text { heifers }\end{array}$ & 1576 \\
\hline 1975 & 2649 & 1370 & 1716 \\
\hline 1980 & 2367 & 1284 & 1847 \\
\hline 1985 & 2250 & 1242 & 1759 \\
\hline 1990 & 1979 & 1145 & 1758 \\
\hline 1995 & 1776 & 1082 & 1566 \\
\hline 2000 & 1272 & 843 & 1576 \\
\hline $2001^{1}$ & 1186 & 812 & 1580 \\
\hline $2002^{1}$ & 1177 & 801 & 1576 \\
\hline $2003^{1}$ & 1162 & 790 & 1579 \\
\hline $2004^{1}$ & 1102 & 742 & 1602 \\
\hline $2005^{1}$ & 1079 & 720 & 1587 \\
\hline $2006^{1}$ & 1106 & 721 & 1549 \\
\hline $2007^{1}$ & 1087 & 648 & 1.534 \\
\hline $2008^{1}$ & 1.057 & 625 & 1.478 \\
\hline $2009^{1}$ & 1.002 & $584(548)$ & \\
\hline
\end{tabular}

Source: RZS Serbia

In Serbia, besides the problem of relatively low average milk yield per cow, the problem of splitting the farms should be added as well, which, according to Popović (2008), in majority of cases, have no prerequisites to produce quality milk, primarely from the hygienic aspect. The same author has established a 
positive correlation between the size of herd, level of average production per cow and price of milk. The larger farms (with 20 and more cows) have advantage in all parameters. Taking into account that the participation of larger farms for milk production in Serbia is still low, along with present great disorganisation of small producers of milk the average price of milk in Serbia is at a considerably lower level in relation to the price of milk in developed countries.

Besides a decrease in the number of farms in the last decade there is a decline in the number of cattle which is $2 \%-3 \%$ at annual level (Table 9). Such a state is reflected directly on the decrease in overall production of milk (which has a negative trend) as well as the production of meat.

\section{Conclusion}

On the basis of the analysis of the state in the sector of milk production in EU and Serbia it can be concluded:

- the level of overall milk production in the countries of EU27 in the last several years ranges from about 148 million tonnes whilst in Serbia there is a decrease in milk production, so in 2009 the production was 1.478 million tonnes, and in 2008 it was 1.7 million tonnes;

- out of total produced milk quantities in EU27 the dairies purchase over $90 \%$, while in Serbia about $50 \%$ milk is purchased;

- a trend in development of cattle production in EU goes in the direction of decreasing the number of farms which raise breeding stocks of dairy cows and simultaneous increase in the number of cows per farms engaged in milk production with constant increase of the quantity of produced milk per cow. Even besides enlarging the farms engaged in milk production, there is a trend of decreasing the number of milking cows (because of achieved high yields of milk per cow in specialised dairy breeds, as well as the supplies of milk), wherein the consequence is the rise in the population of cattle for the production of meat raised in the system cow-calf.

- In 2008 the number of cows per farm in EU27 was on average 9.8 cows, EU25 on average 16.6 cows, with great variation between member countries. An average milk yield in overall population of cows in 2008 in EU15 was $6646 \mathrm{~kg}$, EU25: $6357 \mathrm{~kg}$ and EU27: $6133 \mathrm{~kg}$. Average milk yield of registered cows of Simmental breed in Serbia is around $4500 \mathrm{~kg}$, and Holstein Friesian breed about $8700 \mathrm{~kg}$, while milk yield in total population of cows in Serbia (controlled heads and estimated milk yield of cows) ranges from 3000 and $3500 \mathrm{~kg}$.

- In Serbia, according to the Inventory from 2002, 97.61\% farms had 1 to 5 cows and they owned $87 \%$ of total number of cows in Serbia. In the last 10 years the number of farms engaged in raising cattle decreased, the same as the number of cattle (per annual rate of 2 to $3 \%$ ). Such a state is reflected directly on the decrease 
in total production of milk (which has a negative trend) as well as the production of beef meat.

\section{Acknowledgment}

Paper is financed by the Ministry of Education and Science of the Republic of Serbia.

\section{Stanje u sektoru proizvodnje mleka u Evropskoj uniji i kod nas}

P. Perišić, Z. Skalicki, V. Bogdanović

\section{Rezime}

Analizirano je stanje u sektoru proizvodnje mleka u EU i Srbiji sa aspekta ukupno proizvedenih količina mleka i ukupno otkupljenih količina mleka od strane mlekara. Analiziran je broj gazdinstava koja se bave govedarskom proizvodnjom, kao i gazdinstava koja proizvode mleko. Nivo ukupne proizvodnje mleka u zemljama EU27 u poslednjih nekoliko godina je oko 148 miliona tona, dok je u Srbiji prisutno smanjenje proizvodnje mleka i u 2009-oj godini proizvodnja je iznosila 1,478 miliona tona, a u 2008-oj 1,7 miliona tona. Od ukupno proizvedenih količina mleka u EU27 otkupi se od strane mlekara preko 90\%, dok se u Srbiji otkupljuje oko $50 \%$ mleka.

Trend $\mathrm{u}$ razvoju govedarstva $\mathrm{u}$ EU ide $\mathrm{u}$ pravcu smanjenja broja gazdinstava koja gaje zapate mlečnih krava i istovremenog povećanja broja krava po gazdinstvima, koja se bave proizvodnjom mleka uz stalno povećanje količine proizvedenog mleka po kravi. I pored ukrupnjavanja gazdinstava koja se bave proizvodnjom mleka, prisutan je trend smanjenja broja muznih krava (zbog postignutih visokih prinosa mleka po kravi kod specijalizovanih mlečnih rasa, kao i postojanja zaliha mleka), što kao posledicu ima porast populacija goveda namenjenih proizvodnji mesa, koja se gaje u sistemu krava-tele.

U 2008. godini broj krava po gazdinstvu iznosio je u EU27 prosečno 9,8 krava, EU25 prosečno 16,6 krava, sa velikim variranjem između država članica. Prosečna mlečnost ukupne populacije krava u 2008. godini u EU15 iznosila je 6646 kg, EU25: 6357 kg i EU27: 6133 kg. Prosečna mlečnost umatičenih krava simentalske rase u Srbiji je oko $4500 \mathrm{~kg}$, a holštajn frizijske rase oko $8700 \mathrm{~kg}$, dok mlečnost celokupne populacije krava u Srbiji (kontrolisana grla i procenjene mlečnosti krava) iznosi između 3000 i $3500 \mathrm{~kg}$. 
U Srbiji je, prema popisu iz 2002. god., 97,61\% gazdinstava raspolagalo sa 1 do 5 krava i pri tome su posedovali $87 \%$ od ukupnog broja krava u Srbiji. U poslednjih 10 godina broj gazdinstava koja gaje goveda se smanjivao, isto kao i broj goveda (po godišnjoj stopi od 2 do 3\%). Takvo stanje se direktno odražava na smanjenje ukupne proizvodnje mleka (koja ima negativan trend) kao i proizvodnje goveđeg mesa.

\section{References}

BIGLER A. (2001): Performance increased further. Weitere Auswertungen im Geschaftsjahr 2000/2001, Leistungen weiter gestiegen. Schweizer Fleckvieh, 7, 37-43. PERIŠIĆ P. (1998): Reproduktivne i proizvodne osobine različitih genotipova krava simentalske rase. Magistarska teza, Poljoprivredni fakultet, Beograd.

PERIŠIĆ P., SKALICKI Z., LATINOVIĆ D., TRIFUNOVIĆ G., BOGDANOVIĆ V. (2002): Uticaj udela gena crvenog holštajna na reproduktivne i proizvodne osobine krava simentalske rase. Biotehnologija u stočarstvu, 18, 5-6, 37-43.

PERIŠIĆ P., SKALICKI Z., PETROVIĆ M.M., BOGDANOVIĆ V. (2006): Simentalska rasa i pravci njenog razvoja. XVII Inovacije u stočarstvu, Biotehnologija u stočarstvu, 22, poseban broj, 231-244.

PERIŠIĆ P. (2007): Reproduktivne i proizvodne osobine simentalske rase pri kombinovanom smeru proizvodnje i sistemu krava-tele. Doktorska disertacija, Poljoprivredni fakultet, Beograd-Zemun.

PERIŠIĆ P., SKALICKI Z., PETROVIĆ M.M., BOGDANOVIĆ V., TRIFUNOVIĆ G. (2008). Simentalska rasa u kombinovanoj i specijalizovanoj proizvodnji. Biotehnologija u stočarstvu, 24, posebno izdanje, 25-38.

PERIŠIĆ P., SKALICKI Z., PETROVIĆ M.M., BOGDANOVIĆ V., RUŽIĆ MUSLIĆ D. (2009): Simmental cattle breed in different production systems. Biotechnology in Animal Husbandry, 25, 5-6-1, 315-326.

POPOVIĆ I.R. (2008): Trendovi na svetskom tržištu mleka i uticaj na tržište Srbije. Prehrambena industrija- mleko i proizvodi od mleka, 19, 1-2, 38-43.

STRAPAK P., STRAPAKOVA E. (1997): Milk production of imported fleckvieh cows. Biotehnologija u stočarstvu, 13, 5-6, 281-288.

Izveštaji o sprovedenim merama selekcije na teritoriji Republike Srbije za simentalsku rasu - Institut za stočarstvo - Beograd-Zemun (2010).

Izveštaji o sprovedenim merama selekcije na teritoriji Republike Srbije za holštajn frizijsku rasu - Institut za stočarstvo - Beograd-Zemun (2010).

http:// faostat.fao.org

www. Eurostat (Eurostat and Agriculture and Rural Development DG-C.4, 2009)

www.Cattlenetwork.net (Cattle encyclopedia)

http://www.kis.si 